\title{
AMÂADOI BY LIVIU REBREANU: MULTICULTURAL SETTINGS AND SOURCES OF SUSPENSE $^{13}$
}

\author{
Lucian Vasile BÂGIU \\ "1 Decembrie 1918" University, Alba Iulia \\ Lund University, Sweden \\ e-mail: lucian_bagiu@yahoo.com
}

\begin{abstract}
The article looks into the multicultural settings of Liviu Rebreanu's novel "Amândoi" (Both) by briefly examining the representation of its main, minor or incidental characters, either intelligentsia or common people. Ethnicity, social and professional statuses are considered as elements of multiculturalism. The continuous increase of suspense, the open ending, the parody in the undertone, and the development of the intrigue in an original multicultural context are presented further on. The various rumours arising from the townspeople's own hypotheses about the murders of the aged Dăniloiu provide the opportunity to present the detective genre, which Rebreanu introduced in Romanian literature, suggesting a disguised satire of the type. The archaisms and the regional words of the novel are laboriously registered and underlined in terms of usage, etymology and linguistic connectivity, with the purpose of showing the multicultural flavour by means of a multilingual approach. The essay indicates that all characters use archaisms and local words, notwithstanding their social status or aspirations, a detail that puts in perspective the cultural configuration of the provincial town life, which Rebreanu is very aware of.
\end{abstract}

Keywords: archaisms; detective genre; multiculturalism; provincial Romania; regional words; suspense.

The novel Amândoi, written by the classical Romanian prose writer Liviu Rebreanu, was published in 1940. It is the ninth and the last of his novels and it has been widely considered a lesser work (Călinescu, 1941: 653; Crohmălniceanu, 1954; Piru, 1962; Raicu, 1967: 283). However, Amândoi is notable for its multicultural setting, sources of suspense, regional words and archaisms that give colour to its artistic language, in an endeavour to reveal

\footnotetext{
${ }^{13}$ The present research was supported through Fondul de Dezvoltare Instituţională/ The Fund for Institutional Development, project code CNFIS-FDI-2020-0196, project title: Consolidarea și implementarea politicilor pentru internaţionalizarea Universităţii „1 Decembrie 1918" din Alba Iulia/ Consolidation and implementation of politics for the internationalization of "1 Decembrie 1918” University from Alba Iulia, Romania.
} 
the understanding of multiculturalism as transcending the multiethnic approach (the melting pot theory or the salad bowl theory) to the multilingual tackling.

\section{The multicultural setting: ethnicity and cultural belonging}

The action takes place in Pitești, an important, yet typical, provincial Romanian city (one of the oldest market towns in Wallachia, with a longlasting multiethnic tradition). Following the characters of the novel, one may comprehend some features of the genuine Romanian society around the 1930s.

At the heart of the story is the respectable family Dăniloiu. Its history and social status are perfect exemplifications of the melting pot theory, which asserts that different ethnic groups "abandon their individual cultures and eventually become fully assimilated into the predominant society" (Longley, 2020). The parents of Dăniloiu brothers were Bulgarians, called Danilef, and moved to the Arges river meadows to grow vegetables; they evolved from leaseholders to landlords. They bought a house in Pitești (Ilarie's house nowadays), renamed themselves Dăniloiu (at an advocate's suggestion), and became naturalized at great cost in the Parliament (a hint at bribery). Their father died at 55, already a widower by then. At the time, Ilarie was 30, Spiru -20 and Aretia - 12 years old. Ilarie got married to a Romanian native with dowry, an ordinary way for foreign ethnics, especially Bulgarians, to become more integrated into the Romanian culture and society in Wallachia in the old days. Ilarie Dăniloiu is currently 75 years old, a former merchant, who used to own an ironmonger's shop, which is now sold. He is a money lender in his old age. He is also politically involved, a liberal, and thus a former town councilor, county councilor, deputy mayor, and senator. All of these offices he acquired in his lifetime stand as a testimony for the easy access many foreign ethnics had to the Romanian social and political system once formally integrated into the Romanian culture. Mița Dăniloiu, his wife, 70 years old, is into pawn business. Spiru Dăniloiu, 65 years old, is a shopkeeper in colonial goods, distantly related to the first prosecutor Constantin Negel. Vasilica Dăniloiu, his wife, 57 years old, is a housekeeper. Solomia of Ilie Motroc from Valea Ursului, 21 years old, their maid servant, is a country woman. Aretia Delulescu (born Dăniloiu), 55 years old, believes herself to be of better quality than her brothers, as they remained simple merchants, whereas she got married to Pascal Delulescu, an assistant to the clerk of the court, currently retired.

Among other significant characters, we should mention the priest Tănăsescu, who finds himself dependent on ephors, such as Ilarie Dăniloiu. Mihai Ciufu, 32 years old, is a manservant of the church (or of the priest) and 
a sextant for the last six years. He is a peasant dressed according to townspeople's fashion. Romulus Delulescu, Aretia's son, has a vague degree in law, is a publicist in Bucharest and lives in dire poverty. Dică Secuianu, 36 years old, is the right sort, a good lad, yet a loafer, a tramp, but also the nephew of the first magistrate of the court and thus part of the elite society of Pitești. The town's policeman, inspector Tudor Ploscaru, is of noble descent, commonly known as uncle Tudorică, a jolly elderly man, fond of drinking bouts. The first prosecutor Costică Negel, related through his wife to Pascal Delulescu, is a kind, gentle man, willing to be on good terms with everybody and to bring the law into operation according to social status.

Aurel Dolga, the first examining magistrate, is merely 32 years old, namely, unripe, immature. $\mathrm{He}$ is a Transylvanian recently relocated from Făgăraș, that is, a stranger. Transylvania was, at the time, a province not long ago incorporated into the Romanian Kingdom (at the end of 1918), with a Central European cultural background quite different from that of more Oriental Wallachia. In spite of speaking the same language, Romanians from Transylvania and Wallachia were, in many ways, different. That is why Aurel Dolga is looked upon as a foreigner by Vasilica Dăniloiu, even with hostility: "his silly Transylvanians", in other words, blockheads. In Rebreanu's last novel, multiculturalism is consequently explored even in the case of people belonging to the same ethnic group, but with distinct cultural values (which were, now and then, contrasting, divergent, and incompatible). Therefore, it exemplifies another theory of multiculturalism, the salad bowl, which "describes a heterogeneous society in which people coexist but retain at least some of the unique characteristics of their traditional culture" (Longley, 2020).

Incidental or barely mentioned characters outline the multicultural setting just as well as the main characters. There are common people, some representing various ethnic groups. Such are the street sergeant Lache (a Gipsy from Vieroși), or the famous fiddler Dură the Gipsy, backed by a oneeyed dulcimer player and a limping guitar player. The two hypostases of the Gypsies are a testimony to their cultural integration into the Romanian society, either by practicing a traditional profession (the salad bowl theory of multiculturalism) or as part of the law enforcement (the melting pot approach). A priest from Costești, willing to change dollars he had from a peasant recently returned from America, is a pretext to display international multiculturalism: there were times when peasants were returning from the USA to the Romanian countryside, with money in their pockets - and, presumably, with the capitalistic know-how of the spirit of a multicultural nation par-excellence. Some Transylvanians, present proprietors of Ilarie's shop, stand as evidence of the economic and social integration of the "more recent" Romanian citizens, from the neighbouring historical region of 
Transylvania. Other common people outline the multicultural backdrop by means of their profession. In a rather small (and in many ways rural) town at the time (in 1925, Pitești had 19,617 inhabitants), Lixandru, Solomia's husband, formally named Alexandru Ionescu, currently unemployed, is a former motor-car driver at the branch of the bank Marmorosch-Blank, thus representing both capitalistic and technical achievements. The butcher Mitică Ionescu (a neighbour of Ilarie) and a country priest with his wife (some customers of Spiru) stand for the rustic context. Then, there is the intelligentsia, indicating a solid urban setting. Among its representatives: the defunct advocate Secuianu, a good friend of his neighbour Ilarie Dăniloiu; the county's veterinary surgeon, Haralambie Săvescu; the advocate Trandafirescu; Filofteia Dăniloiu, daughter of Spiru and Vasilica, married to captain Vasilescu, on garrison far away in Sighetul Maramureșului (in Transylvania); the forensic expert Popescu; the clerk of the court, etc. The miscellany of rustic and urban features is yet another way of building up the multicultural framework of the novel.

All of these and many more incidental characters make up a vivid picture of the multicultural city of Pitești in the 1930s, both in its solid wellestablished urban characteristic and in its rustic lingering salient features, a picturesque mixture familiar to many cities of Romania at the time. It is a perfect portrayal of a multicultural community (and hence, of the Romanian society) where people of different races, ethnicities, and nationalities live together. Consequently, Rebreanu's last novel is representative of what is debatably the best performed attribute of his entire work, the social panoptic of Romania in a variety of temporal and geographical focuses.

\section{Sources of suspense}

Unlike his earlier (and most notable) works, the social panoptic (simply sketched in Amândoi) is not, nonetheless, what Liviu Rebreanu intended to bring about mostly in his last novel. The multicultural setting serves as a mere background for a newfangled assembly. According to his own statement (Petrașincu, 1940: 22), Rebreanu tried to set out a new genre in Romanian literature, the thriller-detective story, the police novel, in the tradition of Arthur Conan Doyle or Agatha Christie. Therefore, another important issue is to notice the sources of suspense in the original Romanian novel of a double murder.

In the very first sentence, Spiru Dăniloiu declares that something has happened to his brother, Ilarie, even if at the time he had no idea his brother was dead. The tension is induced from the very beginning of the story: "I wonder what could have possibly happened to my well-off brother?" (Rebreanu, 2016: 7). (All quotations herein were translated from Romanian into English by the author of the article). Thus the reader is convinced that 
something unusual occurred indeed, this is the premise. The wife's talk sanctions the suspicion, from an additional source: she had also conversed with the maid-servant Solomia on the same issue, as Ilarie did not stir for a few days. All of Spiru's neighbours soon agree "something must have happened to Ilarie" (Rebreanu, 2016: 21). The account of the sextant Mihai Ciufu, the character who visited the property of Ilarie on three consecutive days, without coming across anyone, is long-winded; he constantly delays the disclosure, keeps on building suspense. Then the appearance of the servant Ciufu, with a "mug of a villain", is suspicious. He looks as if he keeps something back. All the butchers "are seething with rage" (Rebreanu, 2016: 23): tension is built-up through the spreading of the news of the double murder of Ilarie Dăniloiu and of his wife, Mița Dăniloiu.

Among the various rumours on the identity of the murderer, four find more or less solid reasons. First, the nephew Romulus Delulescu could be the criminal, for their death was in his interest, as he could benefit from their wealth. The hearsay is engendered by the butcher Mitică Ionescu, and whatever he says becomes the talk of the village. Secondly, the neighbour Dică Secuianu may be the culprit, as he had threatened Ilarie publicly he would kill him. The hearsay is set forth by the advocate Trandafirescu, thus it becomes a "scientific assumption". Third, Aretia Delulescu declares that her brother Spiru ordered foreign assassins to kill Ilarie. She has her own interest to spread such rumours: her possible inheritance. Finally, Vasilica Dăniloiu, Spiru's wife, states that the servant of the church, Mihai Ciufu, could be the malefactor for "he has the face of a murderer" (Rebreanu, 2016: 79). He is proven to have lied about the details of his visits to the property of the deceased, thus he keeps back something indeed.

Out of all these, the first prosecutor Negel makes known, by way of joke, that "everybody is a suspect" (Rebreanu, 2016: 28). However, the first examining magistrate Dolga believes this approach to be "very righteous" ( $p$. 28). He feels like the main character in the play which is about to start. Psychologically, he needs to build up a sensational case. He is merely 32 years old, green in his profession, a devout reader of police novels ever since high-school, an admirer of the renowned detectives invented by the imagination of illustrious writers. He wants to be such a detective in real life, a Romanian Sherlock Holmes or Hercule Poirot. The examining magistrate believes everybody to be guilty, or, at least, suspicious, until proven otherwise. In the end, he is the main source of suspense by his means of chaotic investigation. Some literary critics, Vladimir Streinu (1968: 175-188) the first, believe the novel to be an involuntarily satire of the detective story, through its constant ironic undertones and the voice of the author.

Of course, the examining magistrate does not suspect the servant Solomia, the alleged real assassin according to her confession, even if he 
incidentally interrogates her as well. While she admits the double murder, the magistrate still has doubts: "It occurred to him that Solomia might have been constrained to take the blame for the murder to save the real criminal, who he believed to be Romulus Delulescu" (Rebeanu, 2016: 158); "Unless the story was nothing but a make-believe to protect the real wrongdoers." (Rebreanu, 2016: 165) The first prosecutor Negel is also hesitating, as he finds it hard to believe, in his turn, that such a small woman could have killed two people by herself. These feelings of distrust or hesitations are sources of suspense all the same.

The vocabulary used is another source of suspense: "neliniște uneasiness/anxiety", "ingrijorată - anxious/worried", "îi era urât - she diddn't feel at ease", "a tresări - to shudder", "cutremur în șira spinării - a chill down the spine", "infiorându-se - getting chill", "spaimă - fear", "frică - fright", "înfricoșată - frightened", "groază - horror", "îngrozită horrified", "grozăvie - atrocity", "monstruos - awful/monstrous" (our translation).

There is a faint voice of reason in the investigation: the inspector Tudor Ploscaru. The solutions he proposes contradict both the suspicions of the examining magistrate Gheorghe Dolga and the testimony of the seeming murderer, Solomia. He disagrees many times with the examining magistrate, yet without making a stand. He does not judge the case as having many obscure questions, he considers Dică Secuianu capable of killing Ilarie indeed and he notices that the premeditated murder seems to be convenient to the interested relatives. Hence his reasonable explanation, contradicting alternate and more prominent deciphering, acts in itself as a source of suspense. What if he was right, after all?

At the end of the story, a careful reader finds it hard to believe that Solomia is the real murderer and looks for another character as the real assassin. The closure is, actually, an open ending: the conflict is not solved; the final interpretation is left up to the reader.

Thus the policeman Tudor Ploscaru was identified recently as a surprising, yet plausible malefactor, with a comprehensive array of arguments. Among these: his cheerful mood when he was the last to show up at the crime scene and all along the investigation; the word release (or exoneration or forgiveness) ("absolvire") is spoken solely to his character throughout the novel (by non-other than the first prosecutor); he is the first character to be offered an alibi; he is ever ironical all along the investigation; he is the first to make an assumption on the culprit, even before an official investigation begins; when the double-crime is reconstituted, he is the only character not to be mentioned, having no line; even if he is said to have entered the house with all the other investigators, even though the movements of all other characters are carefully monitored, there is no clue to what he is 
doing inside the house, what objects he is touching, etc.; the crime reconstruction is narrated with the visual acuity of an experienced policeman; he is the most autonomous character in the novel, inherently, without any apparent author's awareness; almost all of the information in the novel, essential or merely graphic details, are produced by him, including the story of the hate Dică Secuianu had for Ilarie and his private reasons, the prediction that the relatives will not be part of Ilarie's testament and the remembrance of what Gheorghe Dolga was doing three weeks before (the first examining magistrate having otherwise forgotten that he met Romulus Delulescu beforehand...). He possesses the confidence of a narrator keeping a firm grip on his characters (see Gogu, 2018: 36-44). One more detail should be added: the first prosecutor Negel, when moving from one room to another inside the house, keeps in mind not leaving the commissioner/police officer behind, "lest he should be tempted to assault the pillow with banknotes" (Rebreanu, 2016: 33). The first prosecutor, a gentle man, offering exoneration to the inspector on his first occurrence at the crime scene, may have actually more knowledge and reasons to act in such a tender ticklish manner: he may simply want to protect the real murderer.

Considering the continuous increase of suspense, the open ending, the parody in the undertone, the development of the intrigue in an original multicultural context, Liviu Rebreanu does manage to establish the modern forensic suspense novel in the Romanian literature, considering the lack of that sort of tradition ${ }^{14}$.

\section{Regional words and archaisms}

Liviu Rebreanu's last novel, disregarded by critics, turns out to be original and remarkable when looking into its artistic language as well. When depicting the provincial yet urban Pitești in 1940, the author makes use of many words which are unusual and out of fashion nowadays. This section makes a complete inventory of the local words, archaisms and popular words present in the novel, examining them based on the following criteria: etymological, morphological, quantitative and qualitative occurrence. It aims at making clear how a certain type of multilingualism informs the multicultural society of the time.

The items listed below are ascertained to pertain to regional dialect or archaic language as indicated by the up-to-date dictionaries of the Romanian language (MDA2: 2010; DEX '09: 2009; NODEX: 2002; DER: 1958-1966):

\footnotetext{
${ }^{14}$ Mention should be made of the following novels: M. Bujoreanu, Misterele Bucureștiului, 1862; Mateiu Caragiale, Sub pecetea tainei, 1930; Mihail Sadoveanu, Baltagul, 1930; Victor Eftimiu, Chimonoul înstelat, 1934; Mărgărita Miller Verghy, Prințesa în crinolină, 1946.
} 
- 14 local words: "aținat - half-open", "încaltea - at least", "bloncoasa - excessive high check-bones", "a bruftului - to rebuke", "lihăit - a faint voice, choked with emotion", "năvleagă - silly", "obor - cattle fair", "răpciugos - ragged", "mârșavă - foul", "muruit - soiled", "scârnăvie - vileness", "țaţă - aunt", "vrâstat - striped", "zăbranic - crape".

- 26 archaisms: "boanghină - foreigner", "cârcă - back", "cucoană madam", "dambla - palsy", "a dărăbăni - to drum one's fingers", "gentil - politely", "gingirlie - Turkish coffee with cream", "levent stout", "a ocărî - to reproach", "osteneală - effort", "a se osteni - to make efforts", "ostenit - weary", "a ostoi - to calm down", "logofăt bailiff", "a năpăstui - to wrong", "năpastă - calamity", "prostime rabble", "rărunchi - guts", "a sfeterisi - to prig", "strâmbătate iniquity", "șantan - public house", "tânguire - sorrow", "a zăbovi to stay too long", "zaraf - money changer", "zărăfie - exchange office", "a zălogi - to put in pawn".

By etymological criteria, they are of the following origin:

- 4 Latin: "aținat - half-open", "încaltea - at least", "rărunchi - guts", "strâmbătate - iniquity".

- 20 Slavic: "cârcă - back", "a dărăbăni - to drum one's fingers", "obor - cattle fair", "a ocărî - to reproach", "osteneală - effort", "a se osteni - to make efforts", "ostenit - weary", "a ostoi - to calm down", "logofăt - bailiff”, "mârșavă - foul”, "muruit - soiled”, "a năpăstui to wrong", "năpastă - calamity", "prostime - rabble", "tânguire sorrow", "scârnăvie - vileness", "vrâstat - striped", "a zăbovi - to stay too long", "zăbranic - crape", "a zălogi - to put in pawn".

- 5 Turkish: "dambla - palsy", "gingirlie - Turkish coffee with cream", "levent-stout", "zaraf-money changer", "zărăfie - exchange office".

- 4 Neo-Greek: "cucoană - madam”, "logofăt - bailiff”, "a sfeterisi to prig", "țață - aunt".

- 2 French: "gentil - politely", "șantan - public house".

- 6 of unknown origin: "bloncoasă - excessive high check-bones", "boanghină - foreigner", "a bruftului - to rebuke", "lihăit - a faint voice, choked with emotion", "năvleagă - silly", "răpciugos - ragged".

The origin of these rather peculiar words is in itself a testimony to the history of the Romanian language, an Eastern Neo-Romanic language whose vocabulary has been heavily influenced through the centuries by Slavic languages and, to some extent, by Turkish and Neo-Greek as well. The multilingual history of Romanian is another factor that definitely contributes to the multicultural character of the novel.

Morphologically, the multilingual make-up in the novel is as follows (The analysis is based on a parallel corpus made up of the Romanian source 
text - Rebreanu 2016 - and of the English target text containing our suggestions for translation.)

14 regional words

7 adjectives:

aținat: Latin: a door half-open, ajar/on the jar.

Vasilica Dăniloiu:

- De... știu eu ? fãcu femeia deodată nesigură. N-aș putea spune... După amintire parc-ar fi fost numai aținată [ușa].../ "Well, what do I know?" the woman said all at once, uncertain. "I could not tell... As I remember, I dare say it [the door] was merely half-open..." $\left(\right.$ Chapter XI) ${ }^{15}$

bloncoasă: unknown origin: with excessive high cheekbones.

The narrator:

Chipeș, inalt, [Spiru Dăniloiu.] avea fața bloncoasă, aspră și mustăți stufoase bulgărești mânjite de grăsime./ Good-looking, tall, [Spiru Dăniloiu] had a rigid, excessive high-cheekbones face and a thick Bulgarian moustache, soiled with grease. (Chapter I)

mârșavă: Slavic: disgusting, foul, repulsive, detestable, abominable, loathing.

Gheorghe Dolga:

- Ce bestie de femeie !... (Și adăogă repede, poruncitor:) Aide, mai departe !... De ce te-ai oprit?,.. Mai bine te-ai fi oprit atunci când săvârșeai fapta mârșavă !/ "What a ferocious brute !... (And added quickly, imperiously): Come on, go on! ... Why did you pause? ... You should have better stopped when you were perpetrating the foul deed!" (Chapter XX)

muruite: Slavic: dirty, filthy, soiled.

The narrator:

câteva bucăți de pânzeturi erau căzute pe jos, mai mult muruite decât spălate, iar cele rămase în albie înghețaseră cu rămășițele de apă murdară./ a few pieces of cloths were lying on the floor, more

\footnotetext{
${ }^{15}$ Out of length reason the article specifies only one exemplification for each of the words (its first appearance), no matter how many occurrences each word has or how many characters use it.
} 
soiled than washed, and those left in the tub had frozen with the residues of dirty water. (Chapter IV)

năvleagă: unknown: silly, foolish; awkward, clumsy.

Gheorghe Dolga:

- Cum... așa? strigă judecătorul sărind în picioare. Așa... așa... Ce, ești năbleagă?... Nu știi să povestești?... Să omori știi, iar să povestești nu?/ "How so?" The first magistrate mouthed jumping up. "The like of it... This... You don't know how to tell? What, are you silly? You know how to kill, but to tell you don't?" (Chapter $\mathrm{XX})$

răpciugos: unknown origin: ragged, mangy, shabby.

Romulus Delulescu:

$S$-au creat legende despre portofoliul răpciugos în care sunt ascunse comori misterioase.../Legends have been devised about the ragged wallet concealing mysterious riches... (Chapter XVI)

vrâstat: Serbian: striped, streaked.

Solomia:

(...) bolborosi Solomia, legănându-și capul în dreapta și în stânga, cu glasul plâns şi cu obrajii vrâstați de lacrimi./ (...) muttered Solomia, swinging her head right and left, with a weeping voice and the cheeks striped with tears. (Chapter XXI)

5 nouns:

lihăit: origin unknown: faint voice, choked by/with emotion.

Pe buzele fără culoare ale lui Lixandru înflori un surâs foarte plăpând, iar bulbii ochilor se întoarseră spre Solomia cu aceeași licărire de fericire. Apoi buzele, abia mișcându-se, schițară un lihăit mai mult văzut decât auzit: - Mă... duc.../ On Lixandru's colourless lips blossomed a smile, very feeble, and the eye balls turned towards Solomia with the same glimmer of happiness. Then the lips, hardly moving, outlined a faint voice, choked with emotion, more seen than heard: "I am... going..." (Chapter XV)

obor: Bulgarian: cattle fair, stock market; enclosure, stock yard.

The narrator:

Spiru Dăniloiu avea un mare magazin de coloniale în gura pieții din vale, într-o poziție minunată, lângă podul drumului de fier, încât 
concentra clientela și din piața de legume, și din piața de cereale și de chiristigie până la oborul de vite./ Spiru Dăniloiu had a large shop of colonial goods at the mouth of the market down the valley, in an exceptional location, next to the bridge of the railway line, so that it massed together the customer not only from vegetable market, but also from the market place of grain and timber as far as the cattle fair. (Chapter III)

scârnăvie: Slavic: infamy, vileness, worthless.

Dică Secuianu:

- A fost o scârnăvie unchiul tău Ilarie !/ "Vileness was your uncle Ilarie!" (Chapter XII)

țață: Neo-Greek: aunt; a younger person addressing an older woman respectfully.

Vasilica Dăniloiu:

- Ce vorbeam noi, Solomie, despre țața Mița? intrebă doamna cu o mică satisfacție./ "What were we talking, Solomia, about aunt Mița?" the lady asked with a little satisfaction. (Chapter I)

zăbranic: Bulgarian: crape, black silk formerly used for mourning clothes.

The narrator:

In vreme ce el [Spiru] alergă să se ocupe de cosciuge și de locul de la cimitir, pe Vasilica o trimise să cumpere zăbranicul, lumânările, florile și ce mai trebuiește, lucruri pe care femeile le aranjează mai bine./ While hastening to take care of the coffins and the burial place, he [Spiru] sent Vasilica to buy the crape, the candles, the flowers and what else is needed, matters women arrange better. (Chapter VII)

1 verb:

a bruftului: unknown: to reprove, to rebuke, to scold, to chide, to blow up, to abuse.

Aretia Delulescu:

Pe mine m-a bruftuluit domnul Costică adineaori pentru că am indrăznit să încerc a salva măcar rufăria de pat, iar pe alții i-ați lăsat să cotrobăiască peste tot/Mister Costică rebuked me only just now for I dared to try to salve at least the bed clothes, while you let others to rummage about everywhere (Chapter V) 
1 adverb:

incaltea: Latin: At least; încaltea dacă: if only, at least if.

Solomia:

- Cum nu crezi d-ta, cucoană, la durerea săracului!... Încaltea dacă n-ai cunoaște necazurile mele cu Lixandru mai bine ca mama mea, că nu ți-am ascuns nimic și nu m-am ferit.../ "The way you do not believe in the sorrow of the poor, lady! ... At least if you would not have knowledge of my suffering with Lixandru even better than my mother, cause I did not keep back anything and I did not keep clear of you." (Chapter VII)

26 archaisms

14 nouns:

boanghină: unknown/uncertain origin: Hungarian, Transylvanian; insulting: a person of foreign origin.

Vasilica Dăniloiu:

- Despre boanghina asta am auzit că n-are delicateță nici de două parale... (...) Dacă e mojic, să fie cu nepricopsiții lui de ungureni../ "About this foreigner I heard his tactfulness isn't worth a penny... (...) If he is a cad, let him be with his pitiful Transylvanians." (Chapter XI)

cârcă: Serbian: back (în cârcă, adverbial phrase: on the back, to carry somebody pickaback).

Solomia:

Pentru că mai aveam de lucru, și afară era ger, am luat în cârcă pe Lixandru din căruță și l-am dus în odăița mea, la căldură./ Because I no longer had to work, and there was frost outside, I carried Lixandru pickaback from the cart to my bedchamber, where it was warm. (Chapter XX)

cucoană: Neo-Greek: madam; addressing a lady belonging to an upper social strata.

Mihai Ciufu:

- De, cucoană, știu eu? făcu omul dând din umeri. Se numea Mihai Ciufu și era servitorul bisericii de mai mulți ani./ "Now then, madam, what do I know?" the man said shrugging his shoulders. His name was Mihai Ciufu and he was the sextant for several years. (Chapter I) 
dambla: Turkish: palsy, apoplexy, paralysis; to palsy.

The narrator:

Medicii l-au sfătuit de mult să nu se enerveze, pentru căa, gras şi sângeros, [Spiru Dăniloiu] e amenințat să-l lovească odată damblaua. The doctors advised him for a long time no to chafe, for, corpulent and sanguineous, [Spiru Dăniloiu] is about to palsy some day. (Chapter I)

logofăt: Slavic/Neo-Greek: bailiff (of an estate), manager.

The narrator:

Moșiile erau lucrate ca și înainte. Aveau logofeți și chiar unii zilieri bulgari, de incredere./ The estates were tilled the same as before. They had bailiffs and even some trustworthy Bulgarian daylabourers. (Chapter VI)

năpastă: Slavic: calamity, plague, disaster, calumny, slander; injustice, wrong, iniquity.

Mihai Ciufu:

- Domnule judecător, a căzut năpasta pe capul meu! răspunse servitorul cu un oftat adânc./ "Honourable magistrate, the calamity fell upon me!" the servant answered with a deep sigh. (Chapter XVII)

osteneală: Slavic: pains, trouble, effort, endeavour.

The narrator:

Sergentul ieși cu Ciufu, în vreme ce judecătorul mulțumi preotului pentru osteneală și-i ceru încă o dată scuze că $i$-a pricinuit neplăceri fără voia lui.../ The sergeant went out with Ciufu, while the magistrate thanked the priest for his effort and apologized once again for causing him troubles against his will. (Chapter XVII)

prostime: Slavic: rabble, crowd, ragtail and bobtail.

The narrator:

De la Dică Secuianu auzi că prin prostime circulă zvonul că asasinul ar fi chiar el, nepotul.../ From Dică Secuianu he heard that a rumour is in the air through the rabble that the assassin would be just him, the nephew... (Chapter XII)

rărunchi: Latin: (fig.) depths, inside; (pop: kidney); până în rărunchi, adverbial phrase: to the guts. 
Policeman Tudor Ploscaru:

- Ai s-o cunoști acum [pe familia Dăniloiu], cu ocazia instrucției, până în rărunchi!.../ "Now, on the occasion of the investigation, you are to be acquainted with it [the Dăniloiu family] to the guts!..." (Chapter VIII)

strâmbătate: Latin: injustice, wrongness, iniquity.

Aretia Delulescu:

Tot cu credința în Dumnezeu și dreptate am trăit și ne-am chinuit, că nu se poate să învingă strâmbătatea până la urmă.../ We have kept on living and drudging our lives with the ever faith in God and fairness, for it cannot be that iniquity should come off victorious in the long run... (Chapter V)

șantan: French: pub/public house/dancing saloon where singers and dancers perform in order to entertain the public.

The narrator:

[Dică Secuianu] simțea că e idolul lăutarilor, al cârciumarilor și șantanurilor și al tuturor tinerilor care debutau în viața de petreceri, iar asta îl măgulea.../ He [Dică Secuianu] was feeling that he was the idol of the fiddlers, the publicans and the public houses, and of all the young men coming out in the jollification life, and this was flattering him... (Chapter XIV)

tânguire: Slavic: (Lamentation); grief, sorrow, despair, misfortune, sore distress, suffering.

Vasilica Dăniloiu:

D-na Dăniloiu cunoștea jalea și durerea Solomiei. O dojeni ocrotitor: - Ia taci, fată, nu mai supăra pe Dumnezeu cu tânguiri fără rost!/ Misses Dăniloiu was acquainted with Solomia's despair and woe. She rebuked her protectively: "Now then, keep quiet, lass, stop disturbing God with vain sorrows!" (Chapter I)

zaraf: Turkish: money changer, broker.

Romulus Delulescu:

Am ieșit numai să schimb banii. Dar, oricât sunt de piteștean getbeget, nu cunoşteam zarafii din Pitești, nici nu știam dacă există.../ I went out only to change money. Yet, however much a true-born Pitești fellow I am, I did not have knowldege of the money changers from Pitești, I did not even know whether they existed... (Chapter $\mathrm{XVI})$ 
zărăfie: Turkish: (usury, the action or practice of lending money at unreasonably high rates of interest); exchange office, bank (in the novel).

Gheorghe Dolga:

Doi martori declară că pe la unsprezece, inainte de amiazi, ai fost la Dică Secuianu, de unde tânărul Delulescu te-a trimis să schimbi bani la zărăfie.../ Two witnesses declare that around eleven, in the forenoon, you were at Dică Secuianu, whence young Delulescu sent you to change money at the exchange office... (Chapter XVII)

8 verbs:

a dărăbăni: noun (here, verb), Ukrainian/Polish: drum; to drum one's fingers on the table.

The narrator:

Se așeză la birou, dărăbănind cu degetele un marș nervos./ He set down to the office, drumming with his fingers a vigorous march. (Chapter XX)

a năpăstui: Slavic: to wrong, to do somebody an injustice; to denigrate, to calumniate, to backbite.

Mihai Ciufu:

- N-am omorât, domnule judecător! Nu mă năpăstuiți, domnule judecător.../ "I did not kill, Magistrate! Do not wrong me, Magistrate... (Chapter XVII)

a ocărî: Slavic: to reproach, to blame; to insult, to offend, to outrage, to revile; to speak ill of, to inveigh against.

Mihai Ciufu:

Când a aflat sfințitul că iar n-am dat de dumnealui, s-a făcut borșși m-a ocărât în toate felurile, parcă ar fi vina mea dacă domnul Ilarie nu-i acasă./ When his holiness heard that I did not find him at home again, he flew into rage and reproached me all sorts, as if it was my fault mister Ilarie wasn't in. (Chapter I)

a se osteni: Slavic: to strive to, to endeavour to, to take pains to, to make efforts.

Romulus Delulescu:

Ciufu e foarte guraliv. A încercat să-mi istorisească cum s-a grăbit şi cât s-a ostenit să mă servească mai bine./ Ciufu is very talkative. 
He tried to tell me the way he hastened and how many efforts he made to be of better service to me. (Chapter XVI)

a ostoi: Slavic: to quiet/calm down, to soothe.

Negel :

- Nu s-a plâns, omule, stai, nu exagera iar! zise repede Negel, ostoindu-l parcă./ "He did not complain, look here, stop short and do not exaggerate again!" Negel said quickly, as if calming him down. (Chapter XIII)

a sfeterisi: Neo-Greek: to prig, to filch, to steal.

Negel:

(...) înțelegi, dacă rudele ar fi pus mâna pe exemplarul de aici și ar fi incercat să-l sfeterisească, ar fi ieșit la iveală exemplarul de la București!/ (...) you take the hint, if the relatives had laid hands on the copy over here and had attempted to prig it, it would have come into light the copy from Bucharest! (Chapter XVIII)

a zăbovi: Slavic: to stay too long, to linger/stay/lie/lay behind, to be/come too late, to be behind one's time, to delay (doing something).

The narrator:

Acuma renunță şi trimise pe Solomia singură, mai ales că de la ea pornise gândul. Numai să nu zăbovească prea mult, ca să nu se intârzie cu masa./ This time she gave up and sent Solomia by herself, especially that the mind started from her. But she should not stay too long, so that the dinner would not be late. (Chapter XI)

a zălogi: Slavic: to (put in) pawn, to (give as a) pledge, to put up the spout.

Solomia:

Salba de bănuți de aur o zălogisem de un an la cucoana Mița pentru cinci sute și n-am mai putut-o scoate.../ The golden penny necklace I had put in pawn a year before to madam Mița for five hundred and I could not get it back anymore... (Chapter XX)

3 adjectives:

ostenit: Slavic: tired, weary, worn out.

The narrator: 
[Spiru] a sosit acasă ostenit şi asudat, gâfâind și totuși mulțumit că și-a implinit datoria./ He [Spiru] came home weary and sweaty, gasping and still contended with his fulfilment of duty. (Chapter VII)

gingirlie: Turkish: Turkish coffee with cream

First prosecutor Negel:

- Iubiți, n-aș putea spune - observă Negel aprinzând o țigaretă, după ce sorbi întâi cu zgomot din cafeaua gingirlie./ "Beloved, I could not say" noticed Negel lighting a cigarette, after he firstly drank off noisily from the Turkish coffee with cream. (Chapter XIII)

levent: Turkish: generous, bountiful; vigorous, hale and hearty, stout.

The narrator:

[Aretia] Era proaspăt îndrăgostită de tânărul Pascal Delulescu, practicant fără leafă la judecătorie, care pe-atunci era un băiat levent, drăguț și dezghețat de se scurgeau ochii fetelor după el. Era prima ei dragoste.../ She [Aretia,] had recently fallen in love with the young man Pascal Delulescu, probationer without wages at law court, who was a stout lad at the time, attractive and bright so that the girls eyed attentively at him. He was her first love... (Chapter VI)

1 adverb:

gentil: adjective (here is adverb), French: politely; nicely, gently.

The narrator:

judecătorul s-a purtat foarte , ,gentil".../ the first magistrate behaved very "politely"... (Chapter XII)

Rebreanu must have used the archaisms for most of them were still active words in 1939 (see Scriban, 1939). Nevertheless, the commonsense rationalism of having used the regional words because of his endeavour to depict the characters by means of the geographical dialect of the Argeș County (an idiom he was familiar with as he had lived near Pitești ever since 1930 in his summer house) does not stand. The local words he uses in the novel were in 1939 (and are today) not specific to Argeș county only (or in the larger southern regions of Wallachia and Oltenia), but some originate in the eastern region of Moldavia just as well, while others in the Western region of Banat or in the central region of Transylvania. Thus, one must notice a linguistic inconsistency: in terms of dialectology, people from Argeș County as depicted in the novel do not use a particular geographical dialect, but several geographical dialects, from various regions of Romania. 
Rebreanu was not an academic (he had a military training and served as an officer in the Austro-Hungarian army in his youth) and most likely he was not aware he was making use of an improbable linguistic mixture when writing his novel. The dialectological inconsistency however makes the artistic language of the novel no less appealing to the reader. It is yet another example of multilingualism and multiculturalism.

Part of this vocabulary is used extensively or repeatedly throughout the novel, a testimony to its wide spreading in 1939 or, at least, a stylistic preference of Liviu Rebreanu when writing the novel.

The Neo-Greek archaism "cucoană - madam" (with its variants coană, "cucoane, coane - sir") has no less than 75 occurrences belonging to 11 characters. It comes as a little surprise that the maid-servant Solomia is uttering the word 45 times, mostly when addressing her mistress, Vasilica Dăniloiu, or when referring to another "mistress of the house", the defunct Mița Dăniloiu. For a young maid-servant from the countryside, it is only natural to speak to a city lady (who is also her employer) in a respectful manner. The sextant Mihai Ciufu, a servant and a peasant in his turn, is using the word 6 times, when addressing (or referring) Vasilica Dăniloiu, for all the same reasons. The sergeant Lache (a Gypsy from a village), follows the same pattern with his two utilizations of the word, addressing Vasilica Dăniloiu or referring to the deceased Mița Dăniloiu. Spiru Dăniloiu may also be included into this logic, for his two uses are when speaking about his wife, yet addressing Solomia or reproducing Solomia's talk, thus apparently marking the servant's social and cultural subordination. The examining magistrate Gheorghe Dolga utters the word five times, referring to the departed Mița Dăniloiu, but directly interogating the maid-servant Solomia during her confession, thus, once again, seemingly labelling the social hierarchy. There are, nevertheless, many characters that turn to the same word without any implication of servitude. The advocate Trandafirescu when mentioning Vasilica Dăniloiu to her husband, the forensic doctor Popescu when naming the deceased Mița Dăniloiu, the clockmaker Trandafirescu naming an unknown lady, the first prosecutor Negel addressing Vasilica Dăniloiu, the policeman Tudor Ploscaru talking to Aretia Delulescu and to the first prosecutor Negel. All of these usages should be interpreted as denoting respect, politeness, well behaviour. The word was, at the time, a common manner of addressing in the urban area mostly to a lady (but also with a version for the gentlemen), not necessarily implying social hierarchy or subordination, but simply being well-mannered. The characters using the word, servants, peasants or townspeople, intelligentsia, were marking cultural belonging in the sense that they were all educated. The narrator is using the word in his turn, five times, conveying Solomia's thoughts almost every time. Nowadays the word in use conveying the same meaning is the Latin doamnă. 
Hypothetically, the Greek word was replaced by the Latin word for the latest is more ethnically neutral.

The Neo-Greek regionalism "țță - aunt" has 7 occurrences belonging to 3 characters, all of them referring to their deceased sister-in-law, Mița Dăniloiu. Vasilica Dăniloiu is using the word three times (two times addressing to the maid-servant Solomia and one time speaking to the first magistrate). The defunct was thirteen years older than her, but the main reason for using the appellative is simply showing respect. Aretia Delulescu turns to the same word three times (talking to herself or to the investigators). The departed was fifteen years older but the ground for the usage is, again, paying deference. Spiru Dăniloiu follows exactly the same pattern. What is noteworthy about the usage of this word is its specificity for the countryside local language. As all of the three characters are townspeople, representative of the middle class, the uttering of the word marks an involuntary rustic cultural belonging. Thus the multicultural setting is reinforced by means of social multilingualism. The fashionable word nowadays is the Latin mătuşă.

The Slavic archaism a ocărî has 6 occurrences belonging to 5 characters. With the meaning to reproach, to blame it is used by the sextant Mihai Ciufu (conveying the talk of priest Tănăsescu), by policeman Tudor Ploscaru (reproducing the speaking of the departed Ilarie Dăniloiu) and by the narrator (rendering the speech of priest Tănăsescu). At present the customary synonymic words are any of the Latin a certa or a mustra. With the meaning to speak ill of, to inveigh against (perhaps even to offend), it occurs in the talk of Aretia Delulescu (when talking to her husband about her brother Spiru), by Romulus Delulescu (addressing Dică Secuianu about the departed Ilarie Dăniloiu), and by the narrator (conveying the thoughts of Solomia). These days the ordinary synonymic words are any of the Latin $a$ defäima or the French/Latin a denigra. Once again the word is used by common people or intelligentsia alike, servants originating in the countryside and townspeople of various professions, regardless of any social status. It seemed to have been, at the time and place, a familiar word. Nowadays it evokes an extinct cultural feature.

The Slavic archaism " $a$ zăbovi - to stay too long" has 6 occurrences belonging to 4 characters. Mihai Ciufu utters the word when talking to the first magistrate Gheorghe Dolga, also Solomia in the same circumstances, and Gheorghe Dolga himself when interrogating Romulus Delulescu and Solomia. Moreover, the narrator makes use of the word two times, rendering the thoughts of Vasilica Dăniloiu and the speech of Mihai Ciufu. Thus, the servants, the intelligentsia and the narrator appeal to a word which is, at best, popular today, if not thoroughly archaic. This linguistic borrowing has been replaced today by the ordinary Latin a intârzia. 
The Turkish archaism "zaraf - money changer" has 6 occurrences belonging to 3 characters: Romulus Delulescu is using it three times when talking to Gheorghe Dolga, and, in his turn, the examining magistrate two times when questioning Romulus Delulescu, plus the narrator referring to the sextant Mihai Ciufu. The related "zărăfie - exchange office" has 2 occurrences, belonging to Gheorghe Dolga and to Mihai Ciufu when conversing during the interrogation. A completely obsolete word in contemporary language, it has been replaced by others. Its meaning in the novel is best rendered by bancher (of French origin) and bancă (of Italian and French origin) or, perhaps, schimb valutar (of Latin origin via Italian).

The Slavic archaism "a se osteni - to make effort" has 2 occurrences, belonging to Romulus Delulescu addressing Gheorghe Dolga and talking about Mihai Ciufu, and to Gheorghe Dolga speaking to the policeman Tudor Ploscaru. Today the synonym is a depune efort (of Latin origin via French). The related "ostenit - weary" has 2 occurrences, belonging to the narrator when describing Spiru Dăniloiu. More common synonyms today are the Bulgarian obosit or, with the more extreme meaning of worn-out, extenuat (of Latin origin via French). Lastly, the related noun "osteneală - effort" has 1 occurrence, belonging to the narrator when conveying the speech of Gheorghe Dolga addressed to the priest. The French efort is in use in present times.

The Bulgarian regionalism "zăbranic - crape" has 3 occurrences, belonging to the narrator rendering the thoughts of Spiru Dăniloiu (a Bulgarian by origin), but also describing Solomia or conveying the talk of Solomia's mother, Ioana or those of her brother, Eremia (Romanian peasants). This local word marks a cultural belonging to the region. Its ordinary synonyms are any of the following, both of Latin origin: țesătură or văl de doliu.

The Slavic archaism "a năpăstui - to wrong" has 2 occurrences, belonging to Mihai Ciufu (imploring the examining magistrate) and to the soldier Iacob Cociorvă (addressing Mihai Ciufu). The Latin synonym $a$ nedreptăți is in use today. The related noun "năpastă - calamity" has 1 occurrence, belonging to Mihai Ciufu when talking to the first magistrate. The Slavic noun nenorocire or the French-Latin calamitate or the above mentioned Latin nedreptate are synonyms for the outdated word.

The regional word of unknown origin " $a$ bruftului - to rebuke" has 2 occurrences, belonging to Aretia Delulescu and to the narrator when rendering Aretia's thoughts. It signals a local cultural belonging. The French a brusca is more common nowadays.

What comes out of all these examples is the fact that a good number of words which were very much in use at the time, regardless of any social status implication, have disappeared and have been replaced by others. And 
that those which vanished were of Slavic, Turkish or Neo-Greek origin, whereas those coming preeminent are almost exclusively of Latin, French or Italian origin. The process is familiar to the history of Romanian language. Slavs were present on the territory of nowadays Romania in early Middle Ages, for hundreds of years, around the time when Romanian language was (presumably) in its final steps of configuration. In the end they were assimilated by the early Romanians, but the influence in the language is noteworthy. This was even greater later on, due to the impact of Old Church Slavonic, a cultural language used by the Romanian Orthodox Church all along Middle Ages (The New Testament was first translated and published in Romanian in 1648 in Alba Iulia and the entire Bible in 1688 in Bucharest). The same language was the language of the Romanian elite for about the same period, rulers, nobles wrote administrative, historical, even literary works in Old Church Slavonic (the first written document in Romanian which was preserved is an espionage letter from 1521 written in Wallachia). Ottoman Empire preserved suzerainty over Wallachia (and Moldavia) for more than five hundred years. Although without a direct military presence, their administrative grip was, most of the times, thorough. Hence there was an influence in the Romanian vocabulary. Finally, for around one hundred years (the $18^{\text {th }}$ century) the two principalities were ruled by Greeks, Phanariots from Constantinople/Istanbul, appointed by the Ottoman Empire. An elite social stratum of Greeks had a great impact in the Romanian culture, with some words penetrating the vocabulary. These influences began to be marginalized in the $18^{\text {th }}$ century when the so-called Transylvanian School reLatinized the language by introducing new Latin words instead of vocabulary of other origins. The trend continued in the $19^{\text {th }}$ century when the nobles from Moldavia and Wallachia used to be educated in France (or in Italy), thus bringing massive inputs from the French culture in the country, which resulted in the use of French borrowings in their own literary compositions. What Rebreanu's novel exhibits is a picture of an obsolete provincial Romanian language, with its flavour of multilingualism and, consequently, multiculturalism, an idiom that has become almost extinct in the meantime. It somehow represents the salad bowl theory at the level of literary language. After he published the novel most of the unusual words Rebreanu was still making use of in 1939 were absorbed, made lost.

Another indicative aspect for the multicultural setting is which characters are making use of these words. The narrator makes use of 21 words, about half of the total: bloncoasă, bruftului, cucoană, dărăbăni, dambla, gentil, gingirlie, levent, lihăit, logofăt, muruit, obor, ocărî, osteneală, ostenit, prostime, șantan, vârstat, zaraf, zăbovi, zăbranic. The author does not put regionalisms only in his characters' mouth, just to show some local colour. He uses them to construct the narrative voice too. Having 
the narrator speak in exactly the same peculiar manner as the characters is an argument for the author's authenticity when building up multiculturalism by means of multilingualism. He is not inventing an artistic language by means of choice or selection of words. Liviu Rebreanu is simply using what he must have considered a "natural", colloquial language. As for the characters themselves, the first examining magistrate Gheorghe Dolga makes use of 6 such words: năbleagă, a zăbovi, zaraf, zărăfie, a se osteni, cucoană, mârşavă. The sextant Mihai Ciufu makes use of 6 words in his turn: cucoană, a ocărî, a năpăstui, a zăbovi, zărăfie, năpastă. The maid servant Solomia makes use of 5 words: încaltea, cucoană, a zăbovi, a zălogi, cârcă. Vasilica Dăniloiu - 4: tânguiri, boanghina, țața, aținatăa Romulus Delulescu - 4: a ocărî, zarafii, răpciugos, a se osteni; Aretia Delulescu - 4: a ocărî, țața, a bruftului, strâmbătate; the policeman Tudor Ploscaru - 3: rărunchi, a ocărî, coană; the first prosecutor Negel - 2: a sfeterisi, coană/cucoană; Spiru Dăniloiu - 2: cuconă, țață; Dică Secuianu - 1: scârnăvie; priest Tănăsescu 1: cucoane. It becomes obvious Liviu Rebreanu did not intend to characterize a particular social class or status by means of speech; the archaisms and regionalisms are to be found in equal manner in the case of the common people and of the intelligentsia, it is an element that reflects their belonging to the same hybrid culture.

Mention should be made that Liviu Rebreanu also uses, according to the same latest dictionaries, 39 popular or familiar words, which are, once again, not common to the standard contemporary Romanian language (yet, not necessarily peculiar). Undoubtedly, his reasons must have been stylistic. They are of the following origin:

5 Latin: "colea - over there; near by, not far from here", "deunăzi the other day; recently; a few days ago", "a dosi - to conceal, to hide; to steal", "a lepăda - to hurl, to fling, to throw; to let fall/drop; to lose, to shed; to take off; to leave, to abandon; to give up; to abjure", " (fără) preget ceaselessly, continuously at once, immediately";

17 Slavic: "becisnic - powerless; sickly; weakly; pitiable; poor; harmless fellow", "beregată - throat, gullet, swallow", " $a$ boli - to be ill/sickly/suffering/poorly, to be ailing, to be diseased", "clevetire slandering, defamation, abuse", "cogeamite - huge, as large as life", "a se hlizi - to title, to giggle; to stare", "ibovnic - lover, paramour", "leac remedy, cure; medicine", "a i se năzări - to think that; to fancy that; to picture; to be hallucinated; to cross ones' mind", "povață-advice, counsel", "scârnavă - foul, filthy, grubby; disgusting, infamous, mean, vile, obscene", "simbrie - pay, wages", "smiorcăială - whining, whimpering", "tigvă skull, nut, pate", "trudi - to toil, to labour, to fag; to torture, to grind", "trudit - tired, tired out", "zloată - sleet"; 
4 Hungarian: "simbrie - pay, wages", "sudalmă - oath, curse", "a sudui - to swear, to abuse", "tămbălău - row, shindy, rumpus; junket, high jinks";

3 Turkish: "get-beget - true-born, regular, of the earth, earthly", "matrapazlâc - fraud, swindle", "mușteriu - customer";

4 Neo-Greek: "a se chivernisi - to get rich; to live thriftily", "nepricopsit - poor, stone-broke, hard-up, needy, miserable, pitiful; pauper, poor/indigent person", "a se pricopsi - to enrich oneself, to make one's fortune, to start/spring up", "procopsit - enriched, well-off, well-fixed, settled";

1 French: "bezea - kissing one's hand to somebody, to blow somebody kisses";

6 of unknown origin: "buleandră - rag, shred; duster, rubber; cast-off clothes", "hodorog - old dodderer", "lălâu - clumsy, lubberly, lumbering", "nițel - a little", "sărbezit - turned sour, crabbed, ill-/bad tempered, grumpy, dulled", "a ticlui - to arrange, to form, to make up; to plot, to devise".

The consequence of using these regional words, archaisms, popular and familiar words is the orality and unaffectedness that characterizes both the speech of the characters and the narrative discourse. If we are to agree that "in multicultural communities, people retain, pass down, celebrate, and share their unique cultural ways of life, languages, art, traditions, and behaviors" (Longley 2020), then Rebreanu's last novel is a perfect exemplification of a multicultural community which is very much alive and authentic mostly due to its multilingualism. Therefore, both the common and the specialized reader may find a gem of literary language, which can be assimilated from different perspectives: aesthetic, linguistic and cultural.

\section{Overall conclusion}

Amândoi is a perfect portrayal of a multicultural community (and hence, of the Romanian society) where people of different races, ethnicities, and nationalities live together. Consequently, Rebreanu's last novel is representative of what is debatably the best performed attribute of his entire work, the social panoptic of Romania in a variety of temporal and geographical focuses. Also, considering the continuous increase of suspense, the open ending, the parody in the undertone, the development of the intrigue in an original multicultural context, Liviu Rebreanu manages to establish the modern forensic suspense novel in the Romanian literature, considering the lack of that sort of tradition. What is even more, as a consequence of using a good number of regional words, archaisms, popular and familiar words, is the orality and unaffectedness that characterizes both the speech of the characters and the narrative discourse. Thus, Rebreanu's last novel is a perfect 
exemplification of a multicultural community which is very much alive and authentic mostly due to its multilingualism.

\section{References:}

Călinescu, G. (1941). Istoria literaturii române de la origini până în prezent/ The history of the Romanian literature from its origin until present. București: Fundația regală pentru literatură și artă.

Crohmălniceanu, Ov. S. (1954). Liviu Rebreanu. București: ESPLA.

DER (1958-1966): Dicționarul etimologic roman/ The etymological Romanian dictionary. Alexandru Ciorănescu. Tenerife: Universidad de la Laguna.

DEX '09 (2009): Dicționarul explicativ al limbii române (ediția a II-a revăzută și adăugită)/ The explanatory dictionary of the Romanian language ( $2^{\text {nd }}$ edition, revised and enlarged). București: Academia Română. Institutul de Lingvistică. Editura Univers Enciclopedic Gold.

Gogu, A. (2018). Rebreanu se înșală - Critică detectivistă și metatextualitate latentă în romanul Amândoi/ Rebreanu is wrong - detective criticism and latent metatextuality in the novel Amândoi. In Transilvania. 3/2018, 36-44.

Longley, R. (2020). What is Multiculturalism? Definition, Theories, and Examples. Available at https://www.thoughtco.com/what-is-multiculturalism-4689285, retrieved on January, $12^{\text {th }}, 2021$.

NODEX (2002): Noul dicționar explicativ al limbii române/ The new explanatory dictionary of the Romanian language. București: Editura Litera Internaţional.

MDA2 (2010): Micul dicționar academic/ The small academic dictionary. Ediția a II-a. București: Academia Română. Institutul de Lingvistică, Editura Univers Enciclopedic.

OED (2021): Oxford English Dictionary. The definitive record of the English language. Oxford: Oxford University Press. https://www.oed.com/, retrieved on January, $12^{\text {th }}, 2021$.

Petraşincu, D. (1940). Un roman „poliţist“ de Liviu Rebreanu/ A “police” novel by Liviu Rebreanu. In România literară. II. 51. 31 martie 1940, 22.

Piru, Al. (1962). Prefaţă. Opere alesel Preface. Selected Works. vol. I. București: Editura pentru literatură.

Rebreanu, L. (2016). Amândoi/ Both. București: Editura Hoffman.

Raicu, L. (1967). Liviu Rebreanu, eseu/ Liviu Rebreanu, essay. București: Editura pentru literatură.

Scriban, A. (1939). Dicționaru Limbii Românești/ The Dictionary of the Romanian language. Edițiunea întîia. Iași : Institutu de arte grafice "Presa bună".

Streinu, V. (1968). Pagini de critică literară/ Pages of literary criticism. II. București: Editura pentru literatură. 